\title{
Contents Volume 79, 1999-2000
}

V79, No. 1

J. Smit, Th.E.Wong, C. Kasse \& A.J. van Loon

A new phase in the journal's history $1-2$

D. J. Beets \& A. J. F. van der Spek

The Holocene evolution of the barrier and the back-barrier basins of Belgium and the Netherlands as a

function of late Weichselian morphology, relative sea-level rise and sediment supply 3-16

M.C. Geluk

Late Permian (Zechstein) carbonate-facies maps, the Netherlands 17-27

R.T. van Balen, F. van Bergen, C. de Leeuw, H. Pagnier, H. Simmelink, J.D. van Wees \& J.M.Verweij

Modelling the hydrocarbon generation and migration in the West Netherlands Basin, the Netherlands 29-44

B.D.M. Gauthier, R.C.W.M. Franssen \& S. Drei

Fracture networks in Rotliegend gas reservoirs of the Dutch offshore: implications for reservoir behaviour 45-57

J.J. van Loef

Composition and genesis of rattlestones from Dutch soils as shown by Mössbauer spectroscopy, INAA and XRD 59-71

K.-G. Hinzen \& S. Pietsch

A seismologically motivated survey of blasting activity in the northern Rhine area 73-80

D.A. Nieuwland, J.H. Leutscher \& J. Gast

Wedge equilibrium in fold-and-thrust belts: prediction of out-of-sequence thrusting based on sandbox experiments and natural examples 81-91

T. Zielinski \& A.J. van Loon

Subaerial terminoglacial fans III: overview of sedimentary characteristics and depositional model 93-107

K. Linthout, S.R. Troelstra \& A. Kuijpers

Provenance of coarse ice-rafted detritus near the SE Greenland margin 109-121

V79, No. 2-3

No. $2 / 3$

Special Issue

The Eemian - local sequences, global perspectives

Guest editors: Th. van Kolfschoten \& P. L. Gibbard

Th. van Kolfschoten \& P. L. Gibbard

The Eemian - local sequences, global perspectives: introduction 129-133

J.H.A. Bosch, P. Cleveringa \& T.Meijer

The Eemian stage in the Netherlands: history, character and new research 135-145

W. de Gans, D. J. Beets \& M. C. Centineo

Late Saalian and Eemian deposits in the Amsterdam glacial basin 147-160

R. J.W. van Leeuwen, D. J. Beets, J.H. A Bosch, A. W. Burger, P. Cleveringa, D. van Harten, G.F.W. Herngreen, R.

W. Kruk, C. G. Langereis, T. Meijer, R. Pouwer \& H. de Wolf

Stratigraphy and integrated facies analysis of the Saalian and Eemian sediments in the Amsterdam-Terminal borehole, the Netherlands 161-196

P. Cleveringa, T. Meijer, R.J.W. van Leeuwen, H. de Wolf, R. Pouwe, T. Lissenberg \& A.W. Burger

The Eemian stratotype locality at Amersfoort in the central Netherlands: a re-evaluation of old and new data 197-216

C. Turner

The Eemian interglacial in the North European plain and adjacent areas 217-231

R. Drescher-Schneider

The Riss-Würm interglacial from West to East in the Alps: an overview of the vegetational succession and

climatic development 233-239 
T. Meijer \& R. C. Preece

A review of the occurrence of Corbicula in the Pleistocene of North-West Europe 241-255

G. R. Coope

The climatic significance of coleopteran assemblages from the Eemian deposits in southern England 257-267

T. van Kolfschoten

The Eemian mammal fauna of central Europe 269-281

B. Speleers

The relevance of the Eemian for the study of the Palacolithic occupation of Europe 283-291

A. K. Markova

The Mikulino (= Eemian) mammal faunas of the Russian Plain and Crimea 293-301

A. E Dodonov., A.L. Tchepalyga, C. D. Mihailescu, L. P. Zhou, A. K. Markova, V.M. Trubikhin, A. N. Simakova \& E. G. Konikov

Last-interglacial records from central Asia to the northern Black Sea shoreline: stratigraphy and correlation 303-311

P. Haesaerts \& H. Mestdagh

Pedosedimentary evolution of the last interglacial and early glacial sequence in the European loess belt from Belgium to central Russia 313-324

A.-M. Robertsson

The Eemian interglacial in Sweden, and comparison with Finland 325-333

M. S. Seidenkrantz, K. L. Knudsen \& P. Kristensen

Marine late Saalian to Eemian environments and climatic variability in the Danish shelf area 335-343

M. F. Sanchez Goñi, J.-L.Turon, F. Eynaud, N. J. Shacklcton \& O. Cayre

Direct land/sea correlation of the Eemian, and its comparison with the Holocene: a high-resolution

palynological record off the Iberian margin 345-354

P.C.Tzedakis

Vegetation variability in Greece during the last interglacial 355-367

V79, No. 4

Special Issue

Geochemical mapping in the Kingdom of the Netherlands

Guest editors: P. F. M. van Gaans \& S. P. Vriend

P. F. M. van Gaans \& S. P. Vriend

Geochemical mapping in the Kingdom of the Netherlands: introduction 371-372

D. J. Huisman, J.P.Weijers, L. Dijkshoorn \& A.Veldkamp

Spatial prediction of the variability of Early Pleistocene subsurface sediments in the Netherlands - Part 1:

Heavy minerals 373-380

D. J. Huisman, J.P.Weijers, L. Dijkshoorn \& A.Veldkamp

Spatial prediction of the variability of Early Pleistocene subsurface sediments in the Netherlands - Part 2:

Geochemistry 381-390

L.A.Tebbens, A.Veldkamp \& S. B. Kroonenberg.

Natural compositional variation of the river Meuse (Maas) suspended load: a $13 \mathrm{ka}$ bulk geochemical record

from the upper Kreftenheye and Betuwe Formations in northern Limburg 391-409

H. Middelkoop

Heavy-metal pollution of the river Rhine and Meuse floodplains in the Netherlands 411-428

E. R. V. Busink \& S. Postma

Provincial soil-quality monitoring networks in the Netherlands as an instrument for environmental protection 429-440

D. J. Brus, M. J. W. Jansen \& W. F. de Haan

Designing efficient sampling schemes for reconnaissance surveys of contaminated bed sediments in water courses 441-447

F. van Lienen, G. Frapporti \& A. Stcin

Construction of maps for soil recycling in regional infrastructural works integrating soil-quality laws 449-457 
M. H. G. van Sambeek, H. G. M. Eggenkamp \& M.J.M.Vissers

The groundwater quality of Aruba, Bonaire and Curaçao: a hydrogeochemical study 459-466 F. van den Oever Aruba - a geochemical baseline study 467-477

A. J. de Vries

The semi-arid environment of Curaçao: a geochemical soil survey 479-494 Regular section

W. Z. Hoek

Abiotic landscape and vegetation patterns in the Nctherlands during the Weichselian Late Glacial 497-509

\section{Contents volume 80, 2001}

\section{Volume 80, No. 1}

Special issue

Groningen - Catalist for the North West European oil and gas industr y. Congress Groningen 40 years, 31 May -

1 June 1999

Guest editors: H. Dronkert \& E. Dijlkhuis

W.J.E. van de Graaff

Preface. 3

H. Dronkert

Groningen 40 years, a special issue. 5

J.A. Oele

Conference wrap up. 7

Ms. A. Jorritsma-Lebbink. (opening address)

Gas: Source of prosperity 11

H.J.M. Roels.

Groningen field,past, present and future. 12

G.H.B .Verberg

Groningen, Gasunie and the gas market. 15

P. Mellbye

Non-Groningen gas supplies for Western Europe. 16

Ms A.C.Quinn

Past,present and future of the gas market in the North Sea region. 17

Ch.Burgos

Groningen in the European context. 18

N. van Hulst

Gas: government and market. 19

R.F.M.Lubbers

Groningen - its impact on European society. 20

Acknowledgements 22

L.D. Alblas.

The petroleum industry in the Netherlands - its setting and possible future. 23

K.W. Glennie

Exploration activities in the Netherlands and North-West Europe since Groningen. 33

N. Hoffmann, H. Jödicke \& P. Gerling

The distribution of Pre-Westphalian source rocks in the North German Basin-Evidence from magnetotelluric and geochemical data 71

Th.E. Wong,N. Parker \& P . Horst

Tertiary sedimentary development of the Broad Fourteens area, the Netherlands 85

F.J. Hollman

Integrated gas field development:The Anjum story 95

J.v an Berkel. U. Kaymak, G.Kulawksi, T.Weisenborn \& M. White

Gas field planning tool 103 
E. van der Schans, J.W.N van Lijssel \& P . van Steenderen

Value Analysis:Capturing Total Cost of Ownership reduction opportunities in E\&P projects 107

B.G.Taverne

The concession Groningen: A lawyer's view 113

H.J. Gussinklo, H.W. Haak, R.C.H.Quadvlieg, P.M.F.M. Schutjens \& L. Vogelaar

Subsidence, tremors and society 121

A.F. Correljé \& P.R. Odell

Four decades of Groningen production and pricing policies 137

Volum 80, No. 2

J. van Huissteden, J.C.G. Schwan \& M.D. Bateman

Environmental conditions and palaeowind directions at the end of the Weichselian Late Pleniglacial recorded in aeolian sediments and geomorphology (Twente, Eastern Netherlands) 1

H. Renssen

The climate in The Netherlands during the Younger Dryas and Preboreal: means and extremes obtained with an atmospheric general circulation model 19

C. Diedrich

Vertebrate track bed stratigraphy of the Röt and basal Lower Muschelkalk (Anisian)ofWinterswijk (East Netherlands) 31

J. T: Kloprogge, H. Ruan, L.. V. Duong \& R. L. Frost

FT-IR and RAMAN microscopic study at $293 \mathrm{~K}$ and $77 \mathrm{~K}$ of celestine, SrSO4, from the Middle Triassic limestone (Muschelkalk) in Winterswijk, The Nctherlands 41

P. Buurman,Th. Pape, J. A. Reijneveld, F. de Jong \& E. van Gclder

Laser-diffraction and pipette-method grain sizing of Dutch sediments: correlations for fine fractions of marine, fluvial, and locss samples 49

D.A. Nieuwland and M. Nijman

The atlas of structural geometry: a digital collection of 25 years of analogue modelling

Forthcoming papers

Guide for authors 59

Volume 80, No. 3-4

Special issue

Evaluation of the potential for large earthquakes in regions of present day low seismic activity in Europe.

Workshop at Han-sur-Lesse. Belgium, 13 - 17 March 2000.

Guest editors: T. Camelbeeck, F. Galadini, M. Meghraoui \& M. van den Berg.

Thicrry Camelbeeck, Fabrizio Galadini, Mustapha Meghraoui and Meindert van den Berg

Evaluation of the potential for large earthquakes in regions of present day low seismic activity in Europe 67

M. Sintubin, O. Sels \& P. Buffel

Late Tertiary fault activity in the southwestern boundary fault system of the Roer Valley Graben: evidences from the Bree area (NE Belgium) 69

M. Dusar, J. Rypens, M. Sintubin \& L. Wouters

Plio-Pleistocene fault pattern of the Feldbiss fault system (southern border of the Roer Valley Graben,

Belgium) based on high resolution reflection seismic data

T. Camelbeek, H. Martin, K. Vanneste, K. Verbeeck \& M. Meghraoui

Morphometric analysis of active normal faulting in slow-deformation areas: examples in the Lower Rhine Embayment

K.-G. Hinzen, S. K. Reamer \& T. Rose

Results of Analysis of Digital Elevation Models Used for Site Selection for Paleoseismological Investigations at the Rurrand Fault 
D. Demanet, L.G. Evers, H. Teerlynck, B. Dost \& D. Jongmans

Geophysical investigation across the Peel boundary fault (The Netherlands) for a paleoseismological study K.R. Reicherter \& S. Reiss

The Carboneras Fault Zone (southeastern Spain) revisited with Ground Penetrating Radar - Quaternary structural styles from high-resolution images

K. Lehmann, J. Klostermann \& R. Pelzing

Paleoseismological Investigations at the Rurrand Fault, Lower Rhine Embayment

K. Vanneste \& K. Verbeeck

Paleoseismological analysis of the Rurrand fault near Jülich, Roer Valley graben, Germany: Coseismic or aseismic faulting history?

M. Frechen, K. Vanneste, K. Verbeeck, E. Paulissen \& T. Camelbeeck

The Deposition History of the Coversands along the Bree Fault Escarpment, NE Belgium

Fabrizio Galadini, Paolo Galli, Augusto Cittadini \& Biagio Giaccio

Late Quaternary fault movements in the Mt. Baldo-Lessini Mts. sector of the Southalpine area (northern Italy)

M. Onida, F. Galadini \& F. Forcella

Application of paleoseismological techniques to the study of Late Pleistocene-Holocene deep-seated gravitational movements at the Mortirolo Pass (central Alps, Italy)

E. Masana, J.A.Villamarín, J. Sánchez Cabañero, J. Plaza and P. Santanach

Seismogenic faulting in an area of low seismic activity: Paleoseismicity of the El Camp fault (Northeast Spain)

J. Fleta, P. Santanach, X. Goula, P. Martínez, B. Grellet \& E. Masana

Preliminary geologic, geomorphologic and geophysical studies for the paleoseismological analysis of the Amer fault (NE Spain)

C. Larroque, N. Béthoux, E. Calais, F. Courboulex, A. Deschamps, J. Déverchère, J.-F. Stéphan, J.-F. Ritz \& E. Gilli Active and recent deformation at the Southern Alps - Ligurian basin junction

Fabrizio Galadini, Carlo Meletti \& Eutizio Vittori

Major active faults in Italy: available surficial data

S. Vandycke \&Y. Quinif

Recent active faults in Belgian Ardenne revealed in Rochefort Karstic network (Namur Province, Belgium)

K. Atakan, A. Ojeda, T Camelbeeck \& M. Meghraoui

Seismic hazard analysis results for the Lower Rhine Graben and the importance of paleoseismic data

J.F. Cadorin, D. Jongmans, A. Plumier, T. Camelbeeck, S. Delaby \&Y. Quinif

Modelling of speleothems failure in the Hotton cave (Bclgium). Is the failure earthquake induced?

S. Delaby

Palaeoseismic investigations in Belgian caves

Forthcoming papers 